\title{
PENGETAHUAN TENTANG MEMINIMALISIR RISIKO ERGONOMI DI RUMAH SAKIT
}

\section{Audina Tio Junianti Manik}

\section{audina.junianti@gmail.com}

\section{Latar Belakang}

Di era globalisasi, K3 telah menjadi sebuah kebutuhan dalam setiap bagian kerja baik yang berada dilapangan ataupun didalam ruangan. $\mathrm{K} 3$ adalah suatu bentuk usaha atau upaya bagi para pekerja untuk memperoleh jaminan atas keselamatan dan kesehatan kerja dalam melakukan pekerjaan yang dapat mengancam dirinya baik berasal dari individu maupun lingkungan kerjanya. Dalam Undang-Undang Nomor 23 tahun 1992 tentang Kesahatan, pasal 23 menyatakan bahwa upaya $\mathrm{K} 3$ harus diselengarakan disemua tempat kerja, khususnya tempat kerja yang mempunyai resiko bahaya kesehatan. Begitu juga dengan rumah sakit, tidak lepas dari yang namanya potensi bahaya atau hazard.

Adapun potensi bahaya di rumah sakit dan klinik, selain penyakit infeksi juga ada potensi bahaya lain yang mempengaruhi situasi dan kondisi, seperti kecelakaan (peledakan, kebakaran, kecelakaan yang berhubungan dengan instalasi listrik dan sumber cidera lainnya), radiasi, bahan kimia berbahaya, gas-gas anastesi, gangguan psikologi dan ergonomi.

Ergonomi adalah ilmu serta penerapannya yang berusaha untuk menyerasikan pekerjaan dan lingkungan terhadap orang atau sebaliknya dengan tujuan tercapainya produktifitas dan efesiensi yang setinggitingginya melalui pemanfaatan manusia seoptimal-optimalnya (Suhardi, 2008:2).

Menurut Nurmianto (2005), ergonomi juga memberikan peranan penting dalam meningkatkan faktor keselamatan kerja dan kesehatan kerja, misalnya: menerapkan sistem kerja untuk menurangi rasa kelelahan pada saat melakukan sesuatu kegiatan yang mengakibatkan seluruh tubuh terasa nyeri dan ngilu pada sistem kerangka serta pada otot manusia secara fisiologi.

Menurut PMK Republik Indonesia No. 66 Tahun 2016 menyatakan salah satu dari identifikasi bahaya potensial yang merupakan langkah pertama manajemen risiko kesehatan di tempat kerja adalah 
ergonomic, contohnya posisi statis, manual handling, mengangkat beban.

\section{Metode}

a) Didalam penulisan ini, saya menggunakan metode menganalisis dengan cara mengumpulkan beberapa jurnal dari internet, membacanya, dan juga mengkompilasi isi dari berbagai jurnal tersebut. Dan mengambil serta menetapkan beberapa jurnal sebagai pedoman penulisan ini.

b) Saya mengambil dua jurnal sebagai pedoman.

Jurnal pertama berjudul "Dari jurnal pertama "Pengetahuan ergonomi dan postur kerja perawat pada perawatan luka dengan gangguan muskuloskeletal di dr. H. Koesnadi Bondowoso" oleh Ishana Balaputra dan Adi Heru Sutomo Penelitian analitik menggunakan pendekatan cross-sectional dilakukan melibatkan 39 perawat instalasi rawat inap ruang Bougenvil (interna dan Dahlia (bedah) rumah sakit Koesnadi Bondowoso bulan Februari sampai Maret 2017. Pengukuran pengetahuan ergonomi menggunakan kuesioner yang sudah dilakukan uji validitas dan reliabilitas.
Penilaian sikap kerja menggunakan Ovako Working Posture Analysis System (OWAS), dan pengukuran keluhan gangguan muskuloskeletal menggunakan pedoman Nordic Body Ma p (NBM) $(4,13,14,15)$. Pengukuran sikap kerja menggunakan instrumen Ovako Working posture Analysis System (OWAS). Setelah perawat melakukan perawatan luka, responden diminta mengisi kuesioner Nordic Body Map (NBM) untuk menilai keluhan muskuloskeletal. Analisis bivariat menggunakan uji chi-square dan analisis multivariat menggunakan uji logistik ganda.

Jurnal kedua berjudul "Pengendalian Risiko Ergonomi Kasus Low Back Pain pada Perawat di Rumah Sakit” oleh L. Meily Kurniawidjaja, Edy Purnomo, Nadia Maretti, dan Ike Pujiriani. Metode yang digunakan dalam penelitian ini yaitu metode studi kasus dengan desain potong lintang. Variabel independen yang diteliti adalah faktor risiko ergonomi dan variabel dependennya adalah tingkat risiko ergonomi serta keluhan LBP. Penelitian ini dilakukan dalam 
jangka tahun 2012-2013, di tiga

rumah sakit yang terdiri atas dua rumah sakit pemerintah yaitu rumah sakit militer (RS Bhayangkara) dan rumah sakit sipil yang dikelola oleh pemerintah daerah DKI-Jakarta (RSUD Tarakan), dan satu rumah sakit swasta RSS (nama rumah sakit tidak bersedia dipublikasikan).

\section{Hasil}

Dari jurnal pertama "Pengetahuan ergonomi dan postur kerja perawat pada perawatan luka dengan gangguan muskuloskeletal di dr.

H. Koesnadi Bondowoso" oleh Ishana Balaputra dan Adi Heru Sutomo mendapatkan hasil: masa kerja responden mayoritas 2-6 tahun. Lebih dari lima puluh persen responden memiliki pengetahuan ergonomi kurang baik dan hanya 15 orang $(51,72 \%)$ yang memiliki sikap kerja ergonomis; tidak terdapat hubungan antara jenis kelamin, usia, dan tingkat pendidikan pada perawat dengan keluhan gangguan musculoskeletal. Masa kerja, pengetahuan ergonomi, dan sikap kerja berhubungan dengan keluhan gangguan muskuloskeltal pada perawat; Serta masa kerja, pengetahuan ergonomi, dan sikap kerja berkontribusi sebesar $41,07 \%$ terhadap keluhan gangguan muskuloskeletal.
Dan dari jurnal kedua kedua berjudul "Pengendalian Risiko Ergonomi Kasus Low Back Pain pada Perawat di Rumah Sakit" oleh L. Meily Kurniawidjaja, Edy Purnomo, Nadia Maretti, dan Ike Pujiriani mendapatkan hasil: Data primer hasil observasi mendapatkan aktivitas pekerjaan perawat yang berisiko menimbulkan LBP di Ruang Rawat dan UGD yaitu seperti berikut. Pekerjaan dengan posisi membungkuk, yaitu saat memasang dan melepaskan infus, suction menghisap lender, klisma, merawat dan menjahit luka atau mengganti balutan, resusitasi jantung paru, memasang dan mencabut serta memberi makan pasien via nasogastric tube, mengambil sampel darah, memandikan pasien, memberikan terapi injeksi, serta memasang atau memperbaiki spalk, memasang kateter, dan membuang urin. Pekerjaan yang berhubungan memindahkan pasien dari brankar transportasi ke tempat tidur ataupun sebaliknya, antara lain yaitu pada saat menerima pasien baru ambulans atau dari Unit

Gawat Darurat, mengantar atau menerima pasien dari ruang operasi, mengantarkan pasien untuk pemeriksaan radiologi atau pemeriksaan lainnya dan menerima kembali pasien, mengirim pasien untuk rujukan ke rumah sakit lain. Dari kuesioner dan 
wawancara yang divalidasi berdasarkan rekam medik, didapatkan insidensi tertinggi LBP adalah di Unit Gawat Darurat RSUD Tarakan, kemudian di Ruang Rawat RS Bhayangkara dan terendah adalah di Unit Gawat Darurat RSS. Skor akhir penilaian dengan metode REBA didaSkor akhir penilaian dengan metode REBA didapatkan tingkat risiko sangat tinggi pada aktivitas mengangkat dan memindahkan pasien, sedangkan tingkat risiko tinggi pada aktivitas membuang urin pasien. LBP banyak dikeluhkan setelah memasang infus dan angkat angkut pasien, yaitu terdapat 29 dari 36 responden mengeluh LBP. Semua responden terlibat dalam semua aktivitas pekerjaan (multitasking) namun dengan intensitas dan kekerapan yang berbeda bergantung tugas pokok masing-masing jabatan, hasil penelitian mendapatkan 20 dari 36 responden berisiko sedang dan 16 dari 36 responden berisiko tinggi terkena LBP. Perawat yang bekerja di Ruang Rawat Inap Tahanan RS Bhayangkara yang berjumlah 22 orang, 10 responden di antaranya berusia $\geq 35$ tahun, 12 responden overweight, 14 responden mempunyai tinggi badan lebih dari $155 \mathrm{~cm}, 15$ responden adalah laki-laki, 18 responden tidak mempunyai kebiasaan berolahraga, 12 responden meregangkan otot (stretching) secara berkala di sela-sela pekerjaannya, dan 11 dari 15 responden lakilakinya merokok. Perawat yang berjumlah 22 orang ini bila dihubungkan dengan keluhan LBP, maka didapatkan karakteristik individu yang berhubungan bermakan dengan LBP adalah tinggi badan, kebiasaan merokok, serta jenis kelamin. Hasil analisis bivariat mendapatkan bahwa semua faktor risiko ergonomi itu berhubungan dengan tingkat risiko dan keluhan LBP, yaitu postur kerja membungkuk berisiko 14 kali lebih sering terjadi keluhan LBP bila dibandingkan dengan postur kerja tidak membungkuk; sudut lengkung punggung $\geq 600$ berpeluang 11 kali lebih sering terjadi keluhan LBP bila dibandingkan dengan sudut lengkung punggung lebih kecil dari 600, dan transfer pasien 3 kali atau lebih per hari berpeluang 4 kali lebih sering terjadi keluhan LBP dibandingkan dengan transfer pasien kurang dari 3 kali per hari. Hasil observasi menunjukkan bahwa tempat tidur yang rendah dan tidak dapat disesuaikan dengan tinggi badan perawat, juga jarak antara tinggi tempat tidur dan brankar sebesar 15-20 cm, menyebabkan perawat di RS Bhayangkara dan RSUD Tarakan bekerja dengan postur kerja membungkuk, akan menambah sudut lengkung punggung terutama bagi perawat yang tinggi badannya.

\section{Pembahasan}


Penelitian ini menunjukkan bahwa sebagian besar perawat tidak memiliki pengetahuan yang baik tentang ergonomi di rumah sakit, sehingga situasi ini membuat mereka menghadapi faktor risiko pekerjaan yang serius seperti gangguan muskuloskeletal. Ada penelitian menemukan korelasi pengetahuan ergonomi dengan keluhan gangguan muskuloskeletal pada perawat yang menangani perawatan luka seperti nyeri leher, bahu, punggung, pinggang, dan kaki.

Berdasarkan hasil wawancara mengenai pembinaan dan pengawasan kesehatan dan keselamatan sarana, prasarana dan peralatan kesehatan, rumah sakit telah melaksanakan sesuai dengan peraturan yang berlaku, dimana lokasi rumah sakit yang sudah memenuhi standar, rumah sakit sudah sesuai fungsi, dan alat-alat dikalibrasi setiap tahun. Pembinaan dan pengawasan atau penyesuaian peralatan kerja terhadap SDM rumah sakit belum dilaksanakan pihak rumah sakit karena upaya ini terkait dengan ergonomi dan SDM rumah sakit belum ada yang memiliki kompetensi di bidang ergonomi.Penelitian dari Baraputra dan Sutomo, (2017) menjelaskan bahwa ergonomi dan sikap kerja yang benar harus diperkenalkan di tempat kerja untuk mengurangi resiko gangguan musculoskeletal. Pelaksanaan pembinaan dan pengawasan terhadap lingkungan kerja belum dilaksanakan secara maksimal dimana rumah sakit hanya melakukan pengukuran kualitas udara, kualitas air dan kebisingan. Hal ini tidak sesuai dengan Kemenkes RI No 1087 Tahun 2010 dimana manjemen harus menyediakan dan menyiapkan lingkungan kerja yang memenuhi syarat fisik, kimia, biologi, ergonomi dan psikososial lewat pemantauan secara rutin dan berkala serta melakukan evaluasi dan memberikan rekomendasi untuk perbaikan lingkungan kerja. [gambaran]

Penelitian lain menemukan usia tidak berkaitan dengan gangguan muskuloskeletal pada punggung bawah, punggung atas, leher, bahu, dan ekstremitas atas. Keluhan otot skeletal mulai dirasakan pada usia kerja, yaitu 25-65 tahun. Keluhan pertama biasanya dirasakan pada umur 35 tahun dan tingkat keluhan akan terus meningkat sejalan dengan bertambahnya umur, sehingga kekuatan dan ketahanan otot mulai menurun sehingga risiko keluhan otot meningkat. Pengetahuan ergonomi, sikap kerja, dan masa kerja mampu memprediksi risiko keluhan gangguan muskuloskeletal pada perawat sebesar 41,07\%. Jika pengetahuan ergonomi, sikap kerja, dan masa kerja dikontrol dengan baik, maka risiko keluhan gangguan 
muskuloskeletal dapat dikurangi.

Pengetahuan, keyakinan, dan sikap berperan

pada kecelakaan kerja. Perawat harus

mendapatkan pelatihan teknik kerja yang

baik dalam mengatasi stres dan tekanan

psikologis untuk mengurangi masalah atau

cedera terkait pekerjaan Pengetahuan

ergonomi, sikap kerja, dan masa kerja

mampu memprediksi risiko keluhan

gangguan muskuloskeletal pada perawat

sebesar 41,07\%. Jika pengetahuan ergonomi,

sikap kerja, dan masa kerja dikontrol dengan

baik, maka risiko keluhan gangguan

muskuloskeletal dapat dikurangi.

Pengetahuan, keyakinan, dan sikap berperan

pada kecelakaan kerja Perawat harus

mendapatkan pelatihan teknik kerja yang

baik dalam mengatasi stres dan tekanan

psikologis untuk mengurangi masalah atau

cedera terkait pekerjaan.

\section{Penutup}

Rumah sakit memiliki potensi bahaya yang disebabkan oleh faktor fisik, kimia, biologi, ergonomi dan psikososial.Potensi bahaya yang begitu banyak, mengharuskan rumah sakit menerapkan upaya kesehatan dan keselamatan kerja rumah sakit (K3RS). K3RS bertujuan untuk menjamin dan melindungi keselamatan dan kesehatan bagi sumber daya manusia rumah sakit, pasien, pendamping pasien, pengunjung, maupun lingkungan rumah sakit melalui upaya pencegahan kecelakaan kerja dan penyakit akibat kerja di rumah sakit. Untuk mengurangi risiko ergonomic, diperlukan pendidikan dan pelatihan ergonomic dan sikap kerja yang benar harus diperkenalkan di rumah sakit. Selain pada pekerja di rumah sakit, salah satu aspek yang perlu diperhatikan adalah perancangan produk yang ergonomis adalah kesesuaian spesifikasi produk yang dibuat dengan ukuran dimensi tubuh penggunanya.

\section{Daftar Pustaka}

Balaputra, I., Sutomo A. H. (2017). Pengetahuan ergonomi dan postur kerja perawat pada perawatan luka dengan gangguan muskuloskeletal di dr. $\mathrm{H}$. Koesnadi Bondowoso. Berita Kedokteran Masyarakat (BKM Journal of Community Medicine and Public Health), 33(9), 445-448. Fathi, A., \& Simamora, R. H. (2019, March). Investigating nurses' coping strategies in their workplace as an indicator of quality of nurses' life in Indonesia: a preliminary study. In IOP conference series: Earth and Environmental science (Vol. 248, No. 1, p. 012031). IOP Publishing. 
Jepisah, D. (2020). FAKTOR-FAKTOR

YANG MEMPENGARUHI ERGONOMI

RUANGAN FILLING TERHADAP AKSES

PETUGAS REKAM MEDIS DI RSUD

SIAK TAHUN 2018. MENARA Ilmu,

XIV(1), 43-49.

Kurniawidjaja, L. M., Purnomo, E., Maretti, N., Pujiriani, I. (2014). Pengendalian Risiko

Ergonomi Kasus Low Back Pain pada

Perawat di Rumah Sakit. $M K B, 46(4), 225-$

233.

Mongdong, S., R. Kawatu, P., A., T., Kolibu, F., K.(2019). GAMBARAN

PELAKSANAAN PROGRAM

KESEHATAN DAN KESELAMATAN

KERJA RUMAH SAKIT (K3RS) DI RSUD

MARIA WALANDA MARAMIS

KABUPATEN MINAHASA UTARA.

Jurnal KESMAS, 8(7), 46-53.

PERATURAN MENTERI KESEHATAN

REPUBLIK INDONESIA NOMOR 66

TAHUN 2016 TENTANG

KESELAMATAN DAN KESEHATAN

KERJA RUMAH SAKIT

Putri, O. Z., Hussin, T. M. A. B. R., Kasjono, H. S. (2017). ANALISIS RISIKO KESELAMATAN DAN KESEHATAN KERJA PADA PETUGAS KESEHATAN INSTALASI GAWAT DARURAT
RUMAH SAKIT AKADEMIK UGM. Jurnal Kesehatan, 10(1), 1-12.

Salmawati, L., Rasul, M., Napirah, M. R. (2019). FAKTOR YANG

BERHUBUNGAN DENGAN KEJADIAN

KECELAKAAN KERJA PADA

PERAWAT DI RUANG IGD RSU

ANUTAPURA KOTA PALU. Preventif :

Jurnal Kesehatan Masyarakat, 10(2), 104-

112.

Simamora, R. H. (2020). Learning of Patient Identification in Patient Safety Programs Through Clinical Preceptor Models. Medico Legal Update, 20(3), 553-556.

Soenandi, I. A., Ginting, A., Marpaung, B. (2013). PERANCANGAN ERGONOMIS TEMPAT TIDUR RUMAH SAKIT. Jurnal

Ilmiah Teknik Industri, 1(2), 95 - 102 .

Winihastuti, H. (2016). Hubungan Faktor Risiko Ergonomi dan Keluhan Cumulative Trauma Disorders pada Dokter Gigi di PT. X Tahun 2014. Jurnal Administrasi Rumah Sakit, 3(1), 53-65.

Yuwono, R., Yuamita, F. (2015). ANALISA FAKTOR K3 DAN ERGONOMI TERHADAP FASILITAS PUSAT KESEHATAN UNIVERSITAS UNTUK MENGUKUR KEPUASAN PASIEN. Jurnal Ilmiah Teknik Industri, 14(1), 1-12. 
